\title{
Migration-Security-Development Nexus Approach in Viewing the International Migration Phenomenon of Migrant Workers in West Nusa Tenggara
} Mega Nisfa Makhroja ${ }^{1},{ }^{*}$ Syaiful Anam ${ }^{2}$

\author{
${ }^{1}$ Department of International Relations, University of Mataram \\ ${ }^{2}$ Department of International Relations, University of Mataram \\ *Corresponding author. Email: mn.makhroja@unram.ac.id
}

\begin{abstract}
The increasing number of migrant workers from developing regions to developed countries, which encourages economic improvement in both countries of origin and destination countries, has dominated migration studies by economic and development approaches. The impact of the transnational migration of migrant workers had a significant effect on both the destination country. In destination countries, migrants workers filled the vacancy in the low-level sector (unskilled migrants). Then, the country of origin received remittances to the families left behind to support the economy and regional development. However, migrant workers, on the other hand, are the very vulnerable parties. Examining the case of Migrant Workers from West Nusa Tenggara (NTB), the problems that occur do not stop at the vulnerability of instances of torture, harassment, human trafficking, and narcotics couriers. It develops more deeply in the domestic problems of migrant workers. The high number of divorced marriages and the neglected children of migrants are other security issues that are important to solve. Therefore, this study analyzes the relationship between migrant worker migration from Lombok NTB and its impact on development and security issues, human security. Through the Migration-Development-Security Nexus approach, this study attempts to connect these three crucial issues to get a complete picture of the complexity of international migration of migrant workers from Lombok and Indonesia in general.
\end{abstract}

Keywords: Migration-Development-Security Nexus, International Migrant Workers, West Nusa Tenggara.

\section{INTRODUCTION}

Migration, development, and security are three things that are interrelated but sometimes lead to a conflictual dialectic. On the one hand, migration aims to encourage development in both the country of origin and destination. Still, on the other hand, it poses a security threat (especially human security). The dilemma of development and security in the issue of migration is still a big "challenge" for international relations actors in realizing a procedural, safe, and orderly migration process globally.

Currently, there are limited references about migration, development, and security nexus in South East Asia. However, the migration crisis has risen in Europe and the United States of America since 9/11[1] It became more important since Arab Spring in 2015. There were a massive number of refugees in Europe and the US and affected the increase of populism [2]. The security tension escalates; terrorism and class of civilization issues also appear. This migration, security, and development case is different from the case in South East Asia because, generally, South East Asia only sent migrant workers, not refugees. It should be a further treatment to analyze how migration, development security nexus implication to refugees and workers.

As one of the countries with a high rate of sending migrant workers, Indonesia is still struggling to reduce the problem of sending migrant workers and maximize the potential of migration in promoting national development. So far, Indonesian migrant workers have been placed as workers at the domestic level who have experienced many physical and non-physical violence cases. Some $90 \%$ of illegal migrant workers even experience sexual violence. The government recorded there were 26 types of cases of Indonesian migrants 
from 2017-2019, but the most considerable number of cases are human trafficking and physical abuse [3].

In Indonesia, especially West Nusa Tenggara, the migration process is too closely related to the economy and development because the main driving factor is financial aspects. People migrate because of the lack of opportunities to work. Less education also impacts the chance to get a better job. And surprisingly, this region has supported more than 330-billion-rupiah remittance since 2014-2018 [4]. Ironically, the human Development Index level is still low and ranks 29 out of 34 provinces in Indonesia [5]. Other social issues, such as divorce, put top 10 ranks in Indonesia with 109.000 cases or 2,03\% from its populations [6] and 1 of 7 children in NTB has marriage [7]. The impact of massive migration has not significantly impacted its security protection, especially for migrant workers who experienced any human rights violations.

Then, this research tries to frame migration issues not only focus on the economic perspective of migrant workers but also the security approach as prioritized to strike a balance on how this migration process can run well and smoothly. The research correlates these three concepts, migration, development, and security nexus, to analyze the phenomenon of migrant workers from West Nusa Tenggara.

\section{METHOD}

This study uses a qualitative approach to construct social realities in society and focus on interactive processes or specific events that are more specific [8]. This method was deemed appropriate because of the discussion of migration, development, and security for migrant workers in NTB. The study was conducted by field research and collecting key informants from government institutions such as Mataram Immigration Office, BP2MI West Nusa Tenggara, and the migrant worker. Meanwhile, secondary data was obtained through literature study from International Relations theory books, E-books on migrants' issues and their relation to security and development. The data is processed into a framework and uses the MigrationDevelopment-Security Nexus approach as an analytical tool

\section{FINDING AND DISCUSSION}

\subsection{Migration, development, and Security: Connecting the dot}

The Migration-Development-Security Nexus Model approach seeks to describe the process of sending migrant workers from NTB abroad from an economic and security perspective so that preventive measures can be found to reduce the negative impact of the migration process. Before describing this approach, we will explain in more detail the three concepts and how they are related.

International migration, according to UNHCR, is a process of movement that refers to the direction of people together, usually in an unusual manner and using the same method of transportation-experienced by women, men, and children [9]. This movement of people is caused by several needs, such as asylum seekers, refugees, workers, stateless persons, victims of human trafficking crimes, etc. Meanwhile, The UN Migration Agency (IOM) defines migrants as any person who moves across international borders, past their residence, including people with legal status, the movement is voluntary or not, there is a reason for the move and, there is a period of moving [10].

In this study, the concept of migration is more directed to economic migrants, where people migrate due to economic factors as international migrant workers. Migrant workers are economic actors who contribute to both countries of origin and recipient countries. In this case, the focus will be on migrant workers from West Nusa Tenggara who migrate to earn a decent income.

Development in the broad sense of action is more closely related to economic activity to encourage growth. Meanwhile, in this case, the development approach adopted in this issue includes remittances from migrant workers who work abroad to become one of the sources of state income to drive the local economy.

Meanwhile, security, in this case, is defined as the impact of the migration process that poses threats to human security such as sexual harassment, workplace violence, trafficking in persons, to domestic problems of migrant workers' households. The human security, UN Approach, is an approach to assist people cutting challenges to survival, protection from insecurity feeling[11].

Today, the relationship between migration, development, and security is surrounded by various interests between actors. It puts the migrationdevelopment and security migration relationship at a complex point. This relationship is like a pendulum, where identical development-migration moves positively, while security-migration tends to be negative [12]. The relationship between the two should run side by side, and the key is "migration management" or global governance to create a safe migration process and boost the economy. Migration is not carried out for development, but migration must be placed as a development process. Logical thinking in managing a good migration process will create a policy climate that 
encourages migration, development, and security to run in balance.

\subsection{Migration, Security, Development: Recent Phenomenon}

Several pieces of research explain the issue of migrant workers. The first research belongs to Ashiqah Nur Alami's "Indonesian Regional Diplomacy in ASEAN on the issue of Migrant Workers: The Complexity of Interests of Receiving Countries and Sending Countries' [13]. This study discusses migrant workers in Southeast Asia who have contributed to the region's economic development, but most migrants are still experiencing exploitation and violence. The problem is caused by most workers work illegally, without documents, or use fake documents. In this case, sending and receiving countries should improve the political, economic, and social pillars in the ASEAN Community by promoting the potential and dignity of migrant workers in a peaceful, equal and stable situation, in line with the laws, rules, and policies of ASEAN member countries. In this research, Ashiqah Nur Alami discusses Indonesia's regional diplomacy in ASEAN in the issue of migrant workers, especially in the complexity of the interests of receiving and sending countries in ASEAN countries.

Willyam Saroinsong owns the second research, namely "Handling the Problem of Illegal Indonesia Migrant Worker by the Government of the Republic of Indonesia."[14] This study discusses the problem of illegal migrant workers, which is a complicated and complex problem caused by the legal status of illegal migrant workers. If caught, migrant workers will be punished according to the legal provisions of the destination country, which the $\mathrm{v}$ themselves may not think of as well as the treatment of law enforcement officers in illegal migrant workers countries acting not following existing standards caused by the existence of illegal migrant workers that are not recorded in official documents that provide guarantees for migrant workers in the form of proper protection from officials from the migrant workers country of origin and recipient country officials. To maximize migrant workers' safety, the government has several Memorandum of Understanding (MoUs) with various countries such as Singapore, Malaysia, Japan, Saudi Arabia, and Kuwait to facilitate migrant workers abroad. Based on this, Indonesia has three agencies authorized to handle migrant workers' problems, namely the Ministry of Manpower and Transmigration (Depnakertrans), the National Agency for the Placement and Protection of migrant workers (BNP2TKI), and the Ministry of Foreign Affairs. This research from Willyam discusses more the protection of illegal migrant workers by three government agencies authorized in overcoming the problem of illegal migrant workers during the Susilo Bambang Yudhoyono (SBY) era.

The third research belongs to Ida Hanifah, namely "The Role and Responsibilities of the State in the Legal Protection of Indonesian Migrant Workers with Problems Abroad" [15]. This study discusses the problems experienced by migrants abroad in general. The government's failure to provide job opportunities for the community has made many citizens in their productive age try their luck abroad to earn a living. The government also followed this desire by opening the tap to send male and female Indonesian workers to several countries such as Middle Eastern countries, East Asia, or the closest to Malaysia and Singapore. At least in sending workers abroad, there are 2 (two) benefits obtained by the government, namely reducing the number of unemployed in the country, which then becomes a burden on the state and additional foreign exchange for the country abroad. With the opening of opportunities to work overseas, this cannot be separated from the problems experienced by Indonesian workers in foreign countries. Such as cases of unpaid salaries, migrants failing to leave, termination of employment before the end of the agreement period, disconnection of communication, work not following the work agreement, trafficking in persons, undocumented Indonesian migrant worker, salary deductions exceeding the provisions, and others. Cases of torture and illtreatment of migrant workers are unavoidable facts. The number of cases experienced by migrants abroad has shocked many parties that the state protects its citizens who work abroad.

In this study, Ida Hanifah discusses the problems faced by migrants in general. She provides government protection in protecting troubled migrants abroad, which has been stated in law number 39 of 2004 and has been listed in the goals of the Republic of Indonesia, paragraph 4 opening of the 1945 Constitution.

The fourth research belongs to Ratu Rayanti Arumsari, namely "The Role of the Government of the Republic of Indonesia in the Protection of Indonesian Migrant Workers (TKI) in the Informal Sector in Saudi Arabia."[16] This study discusses the problem of violence faced by migrants. In the informal sector, such as Household Management, they are caused by many factors from abroad and internal factors that trigger violence against the migrants' sector. Informal. Domestic factors include the lack of government oversight of migrants departing agents, the Indonesian Migrant Worker Service Company (PJTKI), or the Implementing Private Indonesian Migrant Worker Placement (PPTKIS). There are many illegal, unregistered migrants departing agents. officially and without written permission from the Ministry of 
Manpower and Transmigration (Kemenakertrans). This is because there are irresponsible parties who want to get big profits from migrants candidates. Therefore, as a form of negotiation effort from the Indonesian government in reaching the problem of placement and protection of migrants, especially Saudi Arabia, on August 11, 2011 the Indonesian government through the Minister of Manpower and Transmigration issued a Manpower Moratorium which applies to the informal sector to Saudi Arabia.

\subsection{Migration Policy: From UN to Local Government}

Global migration management involves actors at high levels, especially governments and international institutions. The cross-border nature of migration requires government regulation in the process. This migration process is then downgraded from the international level to the local level. Starting from the United Nations, UNHCR, ASEAN, the Government of Indonesia, to local governments.

Since 2016, the United Nations has increasingly focused on dealing with the issue of migrant workers through the New York Declaration for refugees and migration, which focuses on the global migration crisis. Another goal is to build commitment between countries on the issue of refugees and migrants. The international community realizes that massive human mobilization raises human security issues: criminal networks, people smuggling, human trafficking, and boat people. The agreement was then signed in December 2018 under the UN Global Compact on Migration (GCM) for safe, orderly, and regular migration [17]. This global agreement is a form of global cooperation expected to create a safe migration mechanism and encourage development. The United Nations, as an international organization, takes an essential role in developing regulations because it has a holistic and comprehensive impact on many countries. This regime needs to be adopted to cover other issues in-depth and comprehensively related to the movement of people across national borders.

This agenda is in line with the 2017-2021 UNHCR Strategic direction. In response to the escalation of migration conflicts worldwide, UNHCR seeks to address the challenges and opportunities that characterize problems for migration and refugees. There are five core jobs: Protect, Respond, Include, Empower, and Solve. UNHCR focuses on the status of refugees under crisis and forced displacement. These strategies adopt the "No one left behind" Sustainable Development Goals and develop new approaches to humanitarian action and recognize the movement of people as not only a humanitarian problem but also a political and development challenge.

At the regional level in Southeast Asia, ASEAN views the issue of labor migration as one of the focuses of cooperation. Several ASEAN members are sending countries for migrant workers. In addition, ASEAN is also a transit country for Middle Eastern refugees. The ASEAN Committee for Migrant Workers (ACMW) is a committee that manages migrant workers under ASEAN. ACMW works in four areas, namely a) Improving the protection and promotion of the rights of migrant workers from exploitation and abuse, b) Strengthening the protection and promotion of the rights of migrant workers by improving the governance of labor migration in ASEAN countries, c) Cooperation regional efforts to fight human trafficking within ASEAN, d) Develop ASEAN instruments to protect and promote the rights of migrant workers.

Indonesia also takes part in coordinating the ACMW Work Plan 2016-2012, namely:

- Research on the rights of migrant workers based on standard employment contracts

- Reintegrating migrant worker return programs

- The same migration campaign with the Philippines

- $\quad$ Building capacity and sharing best practices in labor market management

- Workshop on the protection of migrant workers based on the ASEAN Networking Forum on Labor Inspection.

As a regional forum, ACMW has the mandate to oversee the issue of migrant workers in a more specific direction, namely the protection of migrant workers within ASEAN. Indonesia and the Philippines are two countries that are strong enough to push this issue because of the high number of migrant workers abroad.

At the national level, Indonesia has made several revisions to the migrant worker law. Previously, the Law on the placement and protection of migrant workers no. 39 of 2004 . Based on the articles in the Law, most pieces are more inclined to the placement mechanism than protection. So there is still less focus on dissecting the problems of migrant workers. In addition, Law No. 39 of 2004 does not regulate in detail the role of the central and local governments in creating governance for the delivery of Indonesian migrant workers.

Law no. 39 of 2004 was replaced by Law no. 18 of 2017. This Law revised some of the shortcomings of the previous Law, for example, the governance of placement and protection that did not touch the involvement of the central, regional, and community 
governments - another more detailed regulation regarding insurance and health insurance for migrant workers to reducing field risks. Efforts to protect migrant workers include institutional protection that regulates the duties and authorities of the Ministry as policy regulator and the Agency as policy implementer. The role of institutions at the regional level is essential to encourage better implementation of institutional duties and functions and reduce future risks at the grassroots level through one-stop service. So far, the problem of the dualism of authority between agencies has become one of the challenges in realizing an appropriate system for managing the migration of migrant workers.

At the regional level, the West Nusa Tenggara government takes policies related to international migration governance. Some of the latest regulations related to the delivery, placement, and protection of migrant workers in West Nusa Tenggara are regulated in Governor's Regulation No. 36 of 2019 and the Governor's Regulation No. 40 of 2019. This NTB Governor Regulation No. 36 of 2019 focuses on the technical implementation of the Overseas Work Training Center of West Nusa Tenggara Province. The issuance of this Governor Policy is a follow-up to Law No. 18 of 2017 concerning improving services for prospective migrant workers or Indonesian migrant workers who will go abroad. This work skill improvement is an effort to protect the Indonesian people who will work abroad to reduce the risks in implementing future delivery and placement activities.

\subsection{The Migrant Workers from West Nusa Tenggara Phenomenon}

The history of the migrant worker in west Nusa Tenggara began during the colonialization era when the Dutch Kingdom sent labor to the Dutch Plantation area in Suriname and South America. It started from Batavia 9Jakarta) on 21 Mei 1890. Then the migrant worker in the early independence periods starts July 3, 1947, under the coordination of the Indonesian Ministry of Labor. Then in 2004, enter $3^{\text {rd }}$ period of sending migrant workers under the Indonesian Ministry of Labor and Transmigration. This era, Government Policy order under UU no X Th. 2004 about placement and Protection of Indonesian Migrant Worker [18].

Those periods also impact the condition of migrant workers in West Nusa Tenggara. However, the exceptional cases happened in west Nusa Tenggara workers. Their influence to working abroad to Saudi Arabia or another middle east country because of the religious factor. Most of them want to do Haj or umrah as Muslims. Besides, working in a Muslim country will easily be adapted to Indonesian culture than became a worker in Europe or other Asian countries [19].

The process happened year by year, and West Nusa Tenggara Developed as one of the highest migrant worker origin regions.

\subsubsection{Migration and Development}

Based on Indonesia's Global Worker data, from 2014-2018, West Nusa Tenggara put 4th place as the highest region of sending migrant workers. The first rank was West Java Province, the second was Central Java, and The Third was East Java [20]. In 2014 the number of migrants was 61.139 people $(14,2 \%)$ from Indonesian migrant workers. Based on the Ministry of worker of Indonesia, in 2015, 51.743 workers from West Nusa Tenggara or $18,8 \%$ of Indonesian migrant workers. Then in 2016, there were 40.415 workers or $17,2 \%$ of total Indonesian migrant workers. And in 2017 , there were 34.994 workers or $13,3 \%$ of the whole number of migrant workers (figure 1).

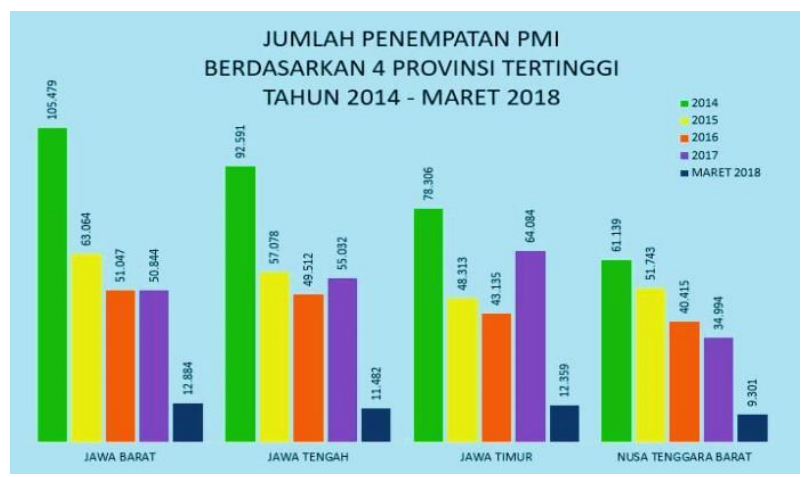

Figure 1. Number of Indonesian Migrant Worker Placement based $4^{\text {th }}$ Highest Rank From 2014-2018

The high number of migrant workers is coherent with the number of remittances. From 2014 to 2016, the average value of remittance is more than 330 billion rupiahs. In 2014, remittance by Indonesian Central Bank is $\mathrm{Rp} 332.267 .041 .470,85$, and $\mathrm{Rp} 396.363 .856 .100,23$

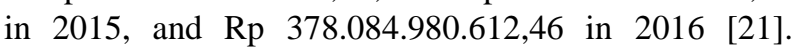
Those numbers are excluded from western union or other unrecorded transactions. It can be achieved by almost $10 \%$ of the regional government budget Rp 5.528.931.855.427 [22].

Migrant workers can collect almost 100 million rupiahs when they return to their homeland and allocate those funds to build a new house, support their children's school, pay the debt, or buy land. There is a limited number of migrants who are consistently starting their small businesses. Some of them may create a small business. Unfortunately, it didn't run well, and they needed an instant solution for their economic problem, then they decided to work abroad again[23]. Then, again economic factors are the central aspect of migrants go 
abroad - however, the high number of remittances is not significantly correlated with the development program.

\subsubsection{Migration and Security}

Discussing the security issue of migrant workers from West Nusa Tenggara is closely related to the significant number of divorces, physical and sexual abuse, overstay, and death by its employee. There were a few sensitive cases of physical abuse regarding women migrant workers in West Nusa Tenggara, such Sumiati, Indonesian workers in Saudi Arabia got physical abuse in 2010 and almost death. Then in 2015, there was Kunep case, she got abuse and cut off her salary [24]. Most cases almost happened in Saudi Arabia and happened to women who work as domestic workers. However, the enthusiasm of people from West Nusa Tenggara to working abroad is not decreasing.

The other security cases in West Nusa Tenggara are about the impact of their migrant family. Many people migrated and left their kids. In one family, mother or father go abroad, and the kids take care of by their relatives. It harms kids' psychological development and social problem in society. It also affected underage marriage in several locations in West Nusa Tenggara.

\subsection{Migration-Development-Security Nexus approach in West Nusa Tenggara Migration}

The impact of regional development on the sending of migrants abroad cannot be measured significantly. Not all migrants are said to be prosperous, so that there is no benchmark for assessing the impact of migrants on development. However, if the example is migrants who can build their own homes and businesses, are independent, and do not rely on working abroad, it can be said that the impact is still not significant for the development of NTB. There are several obstacles, such as most of the migrants departing unprocedural, the lack of data collection on the number of incoming remittances because not all of them use official channels. Some migrant workers work in low-skill fields with low salaries [25]

The impact of sending unprocedural migrants is enormous, including BP2MI and the Indonesian government's difficulty in protecting them because they are not recorded or lost contact. Another case was when migrants who departed procedurally then ran away from work.

After the COVID-19 pandemic, many migrants migrated unprocedural, so BP2MI collaborated with the local police to prevent this problem. The high level of unprocedural migrants has an impact on the high number of human security cases, such as overstay in Saudi Arabia, excess working hours, torture of migrants, especially migrants who work as domestic helpers (PRT), a salary that is not appropriate, too much work, especially migrants who become domestic workers.

The government's efforts to fight for the rights of migrants in Middle Eastern placement countries by further specifying the type of work for migrants domestic workers, for example, how much area must be cleaned, domestic workers explicitly caring for the employer's parents, domestic workers explicitly working in the kitchen and others with the aim that migrants are not overwhelmed do all household work but get a salary that is not following what they do. However, this is still a government plan and has not been realized.

The role of BP2MI Mataram related to migrants protection is carried out from the beginning before departure through special training for migrants, such as language training and for migrants empowerment. In contrast, migrants' security in the country of placement is carried out by continuously monitoring migrants. Regarding the changes in BP2MI Mataram's efforts to protect migrants after the Global Compact for Safe, Orderly and Regular Migration (GCM) 2018 and government Law Number 18 of 2017, concerning the Protection of Indonesian Migrant Workers, it was carried out by realizing the One Channel Placement System (SPSK) program. However, this plan was delayed due to the COVID-19 pandemic. SPSK is a program that aims to connect directly through online communication between migrants and their boss or employer in the country of placement from the beginning before migrants are dispatched to the government of placement or destination country [25].

Meanwhile, related to returner migrants, there are empowerment activities from BP2MI that focus on entrepreneurship training and connecting migrants with entrepreneurs. There are several locations where pilot projects for returnees migrants empowerment activities are located, namely a) Jenggik Village, East Lombok; b) Batujai Village, Central Lombok; c) Mapin Kebak Village, Sumbawa; and d) Growing Mulia Village, East Lombok. In these four villages, Migrant Workers Family Communities were formed, which created three Community Organizers. Each held the task of assisting in handling migrant problems, disseminating job opportunities or Jobs Info, and conducting Entrepreneurship Assistance.

There were several programs for assistance in the security cases of migrants in West Nusa Tenggara. However, the program still focuses on the placement process and didn't address other issues such as preparing before abroad, the quarantine process in Jakarta (waiting for the visa), and placement in the destination. The other missing issue is managing any social problem affected 
by migrant workers left their families and the significant impact of underage marriage.

Unlike other developed countries, the government is much more focused on the work-life balance of the citizen how people have balance time tow work and life with their family, even though when they have kids. This kind of regulation should be put in Government priority in the future policy because sending people abroad impacts economic issues and can create new security challenges.

\section{CONCLUSION}

Based on the Migration-Development-Security approach, the phenomenon of West Nusa Tenggara can be concluded in three things.

First, the migration process of migrant workers still only focuses on an economic issue. The push and pull factors are economical. It is (seemly) denied security (non-traditional) security issues.

Second, the high number of cases of migrant workers mostly happened in unprocedural migrants. It was hard to control and protect the migrant. It is also affected by the low skill of human resources in West Nusa Tenggara.

Third, there were a few policies to protect migrant workers. However, the implementation into the excellent program in bottom level are still rare. Then, the achievement of program is not very effective.

In order to achieve balance between security and economy in migration cases, it is important to put development not as a goals, but development as process, then each actor consider the important aspects of human security too.

\section{REFERENCES}

[1] Riwanto Tirtosudarmo, "The Politics of Migration in Indonesia and Beyond", SPRINGER and LIPI, 2018, pp 197-199, DOI : https://doi.org/10.1007/978-981-10-9032-5

[2] UNHCR, "Press Coverage of the Refugee and Migrant Crisis in the EU: A Content Analysis of Five European Countries", UNHCR, 2014, pp 35, https://www.unhcr.org/56bb369c9.pdf

[3] BP2MI, "Number of cases of Indonesian Migrant Worker 2017-2019”, Indonesian migrant worker protection agency, 2020

[4] BP2MI, "Remittance Data from West Nusa Tenggara 2014-2018”, BP2MI Report, 2019.

[5] BPS NTB, "NTB 2017 : IPMNTB Berada di Peringkat Ke $29 \quad$ Nasional", https://ntb.bps.go.id/pressrelease/2018/04/16/515 /ntb-2017--ipm-ntb-berada-diperingkat-ke-29nasional.html
[6] Ministry of Domestic Affair, "List of Provinces with the Most Living Divorced Population (as of June 30, 2021), Ministry of Domestic Affair Indonesia, 2021.

[7] Duta Selaparang, "Perkawinan Anak Di NTB (1), Satu Dari Tujuh Anak Di Bumi Gora Menikah https://dutaselaparang.com/perkawinananak-di-ntb-1-satu-dari-tujuh-anak-di-bumi-goramenikah/, February 25th, 2021.

[8] W. Laurence Neuman, 'Social Research Method : Quantitaive and Qualitative Approaches", 7th eds, Harlow : Pearson Education Limited, 2014.

[9] UNHCR, “Asylum and Migration”,n.d. https://www.unhcr.org/asylum-andmigration.html

[10] IOM, "IOM Definition of "Migrant"”, n.d.,https://www.iom.int/node/102743\#: :text=I OM\%20Definition\%20of\%20\%22Migrant\%22,f or\%20a\%20variety $\% 20$ of $\% 20$ reasons.

[11] UN, "Human Security", n.d., https://www.un.org/humansecurity/what-ishuman-security/

[12] Adrian A. Smith, 'Migration, development and security within racialised global capitalism: refusing the balance game'. Third World Quarterly, 2016, VOL. 37, NO. 11, 2119-2138, 2016,

DOI http://dx.doi.org/10.1080/01436597.2016.121678 $\underline{3}$

[13] N. Sriyanto \& R. R. E.Yustiningrum,'Diplomasi Regional Indonesia di ASEAN dalam isu pekerja Migran: kompleksitas kepentingan Negara Penerima dan Negara Pengirim', dalam R.E, ashiqah nur alami, Politik Luar Negeri Indonesia dan Isu Migrasi Internasional, Yogyakarta', 2016.p.97

[14] W. Saroinsong, "Penanganan Masalah PMI ilegal oleh pemerintah Republik Indonesia", Indonesian Journal of International law, vol.5, no.4, juli 2008

[15] I.Hanifah,'Peran dan Tanggung jawab Negara dalam perlindungan Hukum Tenaga Kerja Indonesia yang bermasalah di luar negeri', jurnal ilmu hukum, vol.5.no.1, January-June 2020.

[16] R.R. Arumsari,'Peran pemerintah Republik Indonesia dalam perlindungan Tenaga Kerja Indonesia (TKI) sektor informal di arab saudi", Global Political Studies Jurnal, vol.3, No.1, April 2019.

[17] Mega Nisfa Makhroja. 2020. Understanding The UN Global Compact in Migration through Prism of Securitization. Master Thesis. Warsaw : Collegium Civitas.

[18] Badan Nasional Penempatan dan Perlindungan Tenaga Kerja Indonesia (BNP2TKI), 'Sejarah Penempatan TKI Hingga BNP2TKI', Portal BNP2TKI (daring), 27 Februari 2011, <http://portal.bnp2tki.go.id/frame/9003/Sejarah- 
Penempatan-TKI-Hingga-BNP2TKI>, August 1 st, 2021

[19] Mega Nisfa Makhroja, "Migration Network dalam Pengiriman TKI asal NTB ke Saudi Arabia", Thesis, University of Brawijaya, 2012.

[20] Indonesian Ministry of Labor (2018) in Indonesia Global Worker, "The Number of Migrant Workers Placement based on the highest rank in Indonesia 2014-2018', https://indonesiaglobalworker.com/2019/07/05/in ilah-lima-negara-penyerap-pmi-terbesar/

[21] Departement of Labor and Transmigration ,West Nusa Tenggara, 2017.

[22] BPK NTB, "Wagub Serahkan KUA PPAS APBD NTB 2021", https://ntb.bpk.go.id/wpcontent/uploads/2020/12/TOP74.-CB-KUAPPAS-2021-Prov-NTB.pdf

[23] Interview, Sumiyati, Workers in Singapure from West Lombok, October 5th, 2021.

[24] Merdeka, "Kunep, TKW asal NTB dianiaya \& gaji dipotong oleh majikan di Arab", https://www.merdeka.com/peristiwa/kunep-tkwasal-ntb-dianiaya-gaji-dipotong-oleh-majikan-diarab.html

[25] Interview, Asyib Yulianto, Head Secretary of Migrant Workers Protection, BP2MI, August 9th, 2021. 